\title{
COMMUNICATION COMPETENCE AS FUNDAMENTAL ASPECT FOR EFFECTIVE SCHOOL LEADERSHIP AND ADMINISTRATION ACHIEVING: A SYNOPTIC THEORETICAL APPROACH
}

\author{
Panagiotis J. Stamatis ${ }^{1 i}$, \\ Georgios A. Gkoutziamanis ${ }^{2}$ \\ ${ }^{1} \mathrm{PhD}$, Associate Professor, University of the Aegean \\ 1 Democratias Ave., GR-851 32 Rhodes, \\ Greece \\ ${ }^{2} \mathrm{PhD}$ student, University of the Aegean \\ 1 Democratias Ave., GR-851 32 Rhodes, \\ Greece
}

\begin{abstract}
:
Many theories and definitions regarding the concept of Leadership and Management appear in modern literature, as well as interpretations, references to specific characteristics and related topics. This fact shows that over time, a significant effort has been made to clarify the various dimensions of the concept of Leadership and its distinction from the concept of Management. The whole research activity gradually contributed to the development of an important framework in which various and remarkable theoretical models were developed, in parallel with the broader research that has been developed in the field of "human resource management", intending to study leadership styles and managerial behaviors to which they are connected. Many researchers agree that the position of traditional management is completely taken over today by Leadership, which is a complex but flexible, dynamic and at the same time creative resource management process. As has been observed, each new form of Leadership, developed during the 20th century, took into account the effectiveness of the previous one, both in theory and in practice. In this chapter, through three indicative sections, emphasis is placed on the clarification of the concepts of Leadership and Management, concise, conceptual approaches to Leadership Theories and Management Models are developed. Finally, reference is made to the modern, leading role of the School Principal. The characteristic of communication ability is underlined as a fundamental criterion for achieving effective school leadership and administration.
\end{abstract}

Keywords: social media, vocabulary, language learning, positive impact, negative impact

i Correspondence: email stamatis@rhodes.aegean.gr 


\section{Introduction}

Despite the partial similarities in the literature, the concept of Leadership differs from the concept of Management, just as the concept of a leader differs from that of the manager (Bourantas, 2005). In fact, what many usually believe is that leaders manage and managers lead, despite the fact that the concepts of Leadership and Management are not identical. Contrary to popular belief, leaders can emerge through the management arena and managers (administrators, directors, etc.) can exhibit leadership skills. Nevertheless, many managers do not lead and many leaders do not manage (Bass, 1990).

According to West \& Burnham (1997, cited in Everard \& Morris, 2004: 23), the leadership and management of an organization present the following differences:

1) Leadership deals with the vision of an organization, with strategic issues, with transformation, with meanings and systems, seeking to do things right (doing things right).

2) Management deals with implementation, operational issues, transaction, ends, results, and people trying to do the right things.

In a similar context, Manfred F. R. Kets de Vries (2009), referring to the key differences between manager and leader, points out that "managers do things right", while "leaders do the right things". In addition, the common differences between managers and leaders are that leaders are visionary, interested in the future and change, speak to the hearts and souls of their people, inspire and empower, until they eventually take them over gain their trust.

According to Makrigiorgakis (2001: 162), the characteristics of an effective leader could be summarized as follows: "(a) Participates in a common vision with enthusiasm, (b) Becomes a role model himself, (c) Has clear behavior and values, (d) He is a good listener, (e) He encourages initiative, $(f)$ He is sensitive to people, $(g)$ He exhibits endurance and perseverance, $(h)$ He is a liaison/representative of a group or organization, (i) He develops people, (j) He is modest, with a sense of humor, $(k)$ He knows how to set and achieve goals, (l) He knows how to set "limits" and "take the moral high ground".

Each of these characteristics creates in the subordinates the following dynamics respectively: "(a) They accept the goals, "adopt" the project and are interested in its implementation, (b) Consensus prevails in the team as cohesion and team atmosphere is created, (c) Members of the team know his way of thinking, which reflects positively on the most effective execution of instructions, (d) Participation is ensured along with trust and effective problem solving, (e) New ideas and methods are presented, obstacles are overcome, the project is promoted, (f) Interpersonal communication and team spirit are enhanced $(g)$ A prosperous morale is enhanced, (h) A sense of justice is established, (i) A sense of trust and security is induced and a dynamic of motivation and development of initiatives in the group is created, (j)A pleasant atmosphere is provided and respect for the team is developed as a dynamic of mitigation of differences, conflicts, ( $k$ ) Effectiveness is developed, (l) The boundaries of each member are clarified and their respect is expressed". 
Due to heredity, every human being is born with specific genetic characteristics. The basic characteristics of his personality, however, are formed in childhood and adolescence. These include leadership qualities and leadership skills. It is a fact that many people, having the predisposition and making an appropriate effort constantly, methodically and with discipline, can develop and improve their leadership "ability" for life. People are constantly learning and changing. Thus, to whether leaders are born or made, the answer, as stated by Bourantas (2005: 248), is simple: "They are born and made". The leader, in an organization or company, opens new horizons with his actions and expands the framework in which he and his staff act. On the contrary, the "Administrator" is obliged to move procedurally, in typically predetermined frameworks, with little room for self-action. For modern "executives", it is not enough to function only as managers, but it is necessary to function as leaders as well.

Leadership and Management are complementary and interrelated functions. The first concerns offering motivation and orientation to people in order to create better prospects for the future, while the second concerns the effective management of resources (planning, organization, control) available for the realization of short-term results. The most effective executives exercise both Management and Leadership at the same time, or better still, Leadership which does not bypass the principles of Management. In this case, Leadership is manifested, mainly, with the following leadership styles (Ahment, Navaz, \& Khan, 2016):

1) Autocratic. The leader makes the decisions himself and orders the team to implement them. His decisions are dogmatic and he exploits his ability to impose penalties or offer rewards.

2) Democratic. The leader encourages team participation in decision-making, sharing the views or needs of its members.

3) Authorizing (laissez-faire). The role of the leader is limited. The team is not influenced in its decisions by the leader, but is left to decide freely.

4) Strategic. The leader takes care to maintain stability in the team or the company when it functions smoothly and profitably, constantly looking for new opportunities to develop its activities, for the benefit of itself and its employees.

5) Transformational. Employees are constantly pressured to achieve specific work goals, which often change, at the behest of the leader who constantly imposes new, increased tasks and responsibilities.

6) Transactional. Employees are motivated by the leader and take responsibility to increase the productivity and profits of the company in which they work, knowing that they will benefit by receiving a bonus from the growth of profits.

7) Coaching (coach-style). The leader utilizes the skills of members / employees giving importance not only to their work performance but also to their personal and professional development.

8) Bureaucratic. The attitude, the views and in general, the behavior of the leader is based solely on the functioning rules of the team or the company. He does not take 
action and does not allow the development of actions attempted to take place outside the regulatory framework, despite the fact that all views are heard.

There is no clear answer to the question which of the above leadership styles is the most appropriate and effective, because every organization differs from each other, having unique and special characteristics. Thus, each organization imposes, demands and dictates its own particular leadership style depending on the form, nature, object, goals and relationship dynamics that develop internally and externally. This is further influenced by the personality of the leader, the maturity of the associates, the organization, the structure and the operating/functioning model of the organization.

\section{Leadership Theories and Management Models: A Concise Approach}

Reviewing the international literature, it is found that there are hundreds of definitions, various interpretations and approaches regarding the term "Leadership", as a large number of books and studies are published each year focusing on the topic (Bourantas, 2005). It is therefore difficult to adopt a commonly accepted definition of the term "Leadership" that fully addresses theoretical and practical issues related to the nature, structure or conceptual content of the term.

In a brief historical review, it is noted that James McGregor Burns' book "Leadership" was published in 1978. In this book, the author challenges the way of understanding the concept of "Leadership" and at the same time, claims that there are two basic types of leadership: Transactional leadership and Transformational leadership. The first is expressed by the award of rewards or penalties granted depending on the performance of the evaluated by the superior authority. The second is related to a form of leadership that allows for criticism and the collective search for solutions, which encourages participation, information and, more generally, the wielding of power (Bass, 1997).

In a similar context, Kantas (1998) distinguishes Leadership Theories into three broad categories:

1) Those based on the role of leader characteristics,

2) Those based on the examination of the leader's behavior, depending on the characteristics of the prevailing situation and

3) Those that focus on the social and cognitive dimensions of leadership.

More recently, Cheng (2002) discusses two basic theories regarding the concept of "Leadership", which he distinguishes between Traditional Concepts and Transformational Perspectives.

As can be seen from the above three indicative references, the concept of "Leadership" has undergone changes over time, has been enriched and expanded greatly, resulting in being a complex phenomenon today, which is associated with the modern way of managing organizations, companies, policies, educational structures, etc. In an attempt to take a further historical approach to Leadership theories, the basic related management models are briefly presented below. 


\subsection{Classic Management}

In the early 20th century, Frederick W. Taylor was the first to study leadership and human resource management, aiming to maximize worker productivity. The system he proposed, which was quite conservative, was based on the planning of work and the supervision of the "human machines", who avoid taking responsibilities, having the financial reward as their only motive. These views were termed in history under the name of "Taylorism". Based on Taylor's studies in 1916, Henry Gantt reinforced the theory of workforce motivation with a pay system, aiming to increase production and talking about the "time schedule chart", the so-called "production bonus".

Around the same time, Henri Fayol, the foremost inspirer of "management theory", argued that the "Management" of an organization is based on five specific functions, the so-called "management functions", which are, planning, organization, management, coordination and control. These functions are generally accepted, even today. As Makrigiorgakis (2001) characteristically points out, the views of Taylor and Fayol complement each other in essence, because the most significant problem of companies is not the their facilities and equipment but the matters of work and its management, both at the executive level, as well as at the production level, and at all levels of the hierarchy.

Equally important, finally, in the field of classical management was the scientific "contribution" of Max Weber, who, according to his theory of "power structures", pointed out that the best and most effective way of organizing and managing a business or an organization is the one based on power relations and bureaucracy, which is not a negative phenomenon, as a way of organizing large and complex enterprises. The salient features of the bureaucratic concept are the narrowly defined responsibilities, the strict rules and the application of a hierarchical-pyramidal way of organization.

\subsection{Neoclassical Administration - The "Schools of Behavior"}

While the "classic" views on the management of organizations or companies aimed at increasing productivity and output performance of employees, focused more on improving working conditions, employee specialization and linking production to remuneration, the Neoclassical Management Model is based on the employee and his needs, in human relations, asserting that effective Management can be exercised only if human behavior is understood and human relations and actions are promoted within the organized working group.

Mary Parker Follett has contributed to the development of this model, initially expressing the view that employees are influenced through the participating teams, because the team has the power to control members and their activities (Saitis, 2007). However, Elton Mayo, who worked on research in the field of human relations developing in the work environment, undoubtedly has a substantial contribution to the development of this model (Makrigiorgakis, 2001). In a similar vein, Chester Irving Barnard added that the achievement of an organization's goals is accomplished through "collective effort" and acceptance of superiors by hierarchical subordinates. 
Later, in 1960, Douglas McGregor published his book, The Human Side of enterprise, in which he described and compared the conflicting theories of Taylor $(X)$ and Mayo ( $\mathrm{Y}$ ). According to theory (X), man does not want to work, avoids taking responsibilities and his only motivation for work is remuneration. Theory $(\mathrm{Y})$ recognizes human relationships as a factor that can improve employee performance and therefore, the productivity of an organization (Makrigiorgakis, 2001). McGregor's ultimate goal was to motivate employees with internal motivations in order to increase their efficiency and productivity, which is why his theory shows the characteristics of a humanitarian approach. Nevertheless, there have been researchers who have accused McGregor of failing to substantiate what he was saying, because, after all, management is sufficiently flexible and dynamic and has the ability to act accordingly in every situation, showing flexibility in diverse situations.

\subsection{Modern Administration}

The first Model of Modern Administration officially appears in the late 1950s. Its difference from previous models, which are distinguished for their one-sidedness, lies in its synthetic character. Essentially, in the context of this model, increase of the efficiency of an organization is examined, when through the production process, certain motives are satisfied, which are based on the demands of the employees. Modern models, proposed for more effective management in systems or organizations, are influenced by current scientific trends, as they are shaped mainly by the findings of psychological and sociological research. In this context, the following main representative from the respective scientific fields are briefly mentioned, who with their views contributed to the formulation and promotion of modern management models.

\subsection{Modern Management Models: School of Social Systems}

The founder of the Modern Management Model is considered to be Chester Barnard, who, trying to clarify the function of Management, formulated the theory of cooperation. According to this theory, humans form organizations to achieve common goals. The secret of efficiency lies in the team effort, compensating for any biological, physical and social limitation of their abilities (Saitis, 2007).

In the same model of Management, other eminent scientists contributed, such as A. Maslow, who developed the Motivation Theory in 1940. Maslow argued that each person's degree of motivation is affected by the degree to which his needs are not met. Therefore, needs are "motivating" when they are not met. Unsatisfied need is a powerful motivator for every human being. A need that has already been satisfied at an earlier stage may function again as the main motivating force (regression phenomenon) (Theophilides, 1994).

Getzels and Guba (1957), who studied organisms from the perspective of the social system, report that social behavior is a relationship that arises from the interaction between one's undertaken role and his personality. Thus, each system must strive to be successful, in order for its goals to be aligned, as much as possible, with the needs and 
interests of the people who hold the specific positions within the system (Pasiardis, 2004). It is estimated that, only then conflicts will be reduced and the achievement of the organization's goals will be faster and more efficient.

In a similar way, Frederick Herzberg developed the theory of two-factor theory in 1968, after research concluded that there are two categories of factors that affect human behavior. The first category includes the factors that cause a positive attitude towards work, while the second category includes the factors that cause an unfavorable attitude, i.e. there are factors that cause satisfaction and factors that create dissatisfaction in employees.

Later theories confirm the fact that the psychological state of employees affects their efficiency. Such a theory is, for example, the theory of immaturity-maturity, which is developed in the book of Chris Argyris (1957) entitled "Personality and Organization: The Conflict between System and the Individual". According to this theory, employees must participate and contribute to decision-making concerning their employer, so that they are given the opportunity to utilize and develop their skills and creativity. Therefore, the budgets of the organizations should be formulated by taking into account the opinion of those who work in them and not by enforcing decisions of central management on the employees.

Finally, Rensis Likert (1961) expressed the view that the ideal management system is the "participative" management, arguing that organizations that follow this leadership style are more efficient and productive. The principles of participative management style can be applied to all types of organizations, as long as the "leader" has confidence in his team members. In this case, decisions are taken through democratic procedures developed with the consent of the members, on the basis of the "majority principle". The main things in this case are two-way communication and teamwork.

\subsection{Models of Modern Management: School of Psychological Systems}

Equally important contributors in the study of human behavior were leading scientists in psychoanalysis and psychiatry. The first was Sigmund Freud, who formulated his Psychoanalytic Theory which included the basic concepts (Id, Ego, Superego), the mechanisms of adaptation and psychological defense, the psychosomatic development of the individual. Carl Jung followed Freud, emphasizing the development of personality and not the treatment of mental illness and Alfred Adler, pointing out that personality can develop normally only within the framework of rules set by the social environment. From the above management models, it is concluded that each organization is a system consisting of subsystems. A change in any subsystem creates chain effects in the other subsystems. For this reason, every responsible manager or leader must constantly take care of the smooth functioning not only of the central system but also of all subsystems. An exemplar model of this is the human organism, the human body, the understanding of the overall mode of functioning of which presupposes the understanding of the mode of functioning of its parts. 


\subsection{Total Quality Management (TQM), with emphasis on education}

The roots of Total Quality Management (TQM), which is a modern form of management, are found in the human relations movement. The father of this theory is Edward Deming (1983, 1986) and its successors are Joseph M. Juran (1994) and Ned Crosby (1995) (Athanasoula-Reppa, 2008). The TQM was first applied in 1949 in Japanese industries, aiming at directly improving productivity. It is called "total" because it proposes the participation of everybody involved, and especially the employees of the company, in the production process and "quality" because it focuses more on the quality of the products produced, the needs and desires of the customer rather than profit, in the narrow sense of the term. The TQM is a modern management model. Achieving goals for continuous quality improvement, is based on the excellent correlation of all factors of production that participate in a business.

Zavlanos (1998) states that for the implementation of Total Quality Management, the following elements are necessary:

a) The existence of effective leadership that will be able to find and promote, together with the staff, a vision for the organization

b) Staff education and training

c) The communication of the staff which should take place between all the members at the level of organization (internal) and the level of communication with the customers (external)

d) The development of internal incentives and recognition for employees, as cooperation between members is imperative and should be encouraged by managers and

e) The measurement of the operating system of the organization.

The TQM is considered the response of companies to the modern demands of society for continuous improvement of the quality of products and services. Therefore, it can be characterized as a "management model" in which success depends on the pursuit of the optimal combination of all the productive factors of a company or an organization, using not only the inferences of management but of other sciences as well, such as, sociology, statistics and psychology.

The TQM model in education, uses several elements from its application to business, which, however, modifies them to suit and characterize the educational processes. The continuous improvement of the educational process is carried out by a set of principles, which by applying quality methods based on the rational utilization of human resources, lead to more efficient and more quality educational services. These services concern all those involved in the matters of education (teachers, students, parents) and not only the managers of each level of educational administration. In this context, each teacher who undertakes a project, after putting his own "seal" on it, transfers it to another teacher or to the next educational level and so on.

However, a question which arises is: "Is it possible to implement the TQM, given the current structure of the Greek educational system?" The answer to this question is considered obvious, if we take into account the general situation that prevails today in 
the field of administration in many countries. Some of the following reasons contribute negatively to the exertion of TQM, as evidenced by the quality results that appear in the daily routine of services:

a) The centralized administrative system.

b) The confusion of roles created by unclear legal frameworks and their implementation at will by respective administrators.

c) The non-application of the collective spirit in the administration.

d) The lack of implementing evaluation at the level of educational output, of teachers and other parameters of quality education.

e) Lack of tools and equipment and inadequacy of educational infrastructure.

In addition to addressing the above problems, the conscious activation of teachers is proposed, as a measure of application of the TQM, in order to implement targeted actions to improve all quality indicators of education.

\section{The Principal as a Leader in the modern School Unit}

The modern role of the school principal has changed. It is no longer handling administrative and service matters as it used to be, but it is multidimensional and complex (Saitis, 2005). He is responsible for the operation of the school unit, which he organizes and directs / manages by coordinating a specific group of people, with different cultural and educational characteristics. It attempts to reform and upgrade the educational output of the school unit, motivating the teachers and utilizing all the offered incentives. Uses persuasive and supportive language, seeks to improve the performance of teachers to meet higher educational and administrative goals, in a calm and cooperative ambience/climate, with a team spirit, utilizing good communication practices in all processes and relationships that develop daily in the school (Stamatis \& Hatzinikolaou, 2020).

All this requires the principal to be a "role model" for didactic, pedagogical, professional, service and interpersonal issues, to empower all members of the school community and especially of teachers, students and parents in the efforts they make and the initiatives they undertake inside and outside of school (Bennett, Crawford, \& Cartwright, 2002). The contemporary principal facilitates the communication between the teaching staff both with each other and with him, as well as with other bodies, outside the school unit. Provides specific teaching and pedagogical instructions to the teachers of the school unit, motivating and encouraging them to take initiatives, in order to use their skills, their abilities and their interests, in order to carry out effective teaching and consequently produce excellent educational output (Hanson, 1996; Mortimore, 1992).

In addition, it is essential to contribute to the planning of the administrative, teaching and educational output provided in the school unit, to the evaluation of the teaching staff and to the improvement of teaching and learning, seeking close cooperation with others and avoiding the application of authoritarian perceptions which invariably lead in conflict situations (Owens, 2001). He is also considered a "Leader", a link between 
teachers and a communication hub, regarding the management of the flow of incoming and out-coming information of the school unit he represents. For this reason, he must acquire communication skills, in order to be able to argue, to have the power of persuasion, to have personal prestige and to cultivate mutual respect between the teaching staff and society (Stamatis, 2011). Finally, he must be able to maintain the smooth running of the school, effectively motivate teachers and create opportunities for their training, in order to contribute to their professional development.

According to Theophilides (1994, cited in Vitsilaki \& Raptis, 2007: 79), regarding the ways to improve school efficiency, an effective principal should:

- Work systematically in order to have achievements in the field of learning.

- Create a work climate that emphasizes high expectations.

- Be a source of reference in teaching matters.

- Be an energetic and active leader.

- Seek cooperation with staff.

- Take care of the proper operation and order in the school environment.

- Utilize school resources.

- Make good use of time.

- Evaluate the success of goals.

Of course, the above-mentioned characteristics are not enough to describe the features of a modern, effective manager. As Andrews \& Soder (1987: 6) characteristically state, "the most important trait of an effective principal is to be ubiquitous in school." He also needs to have according to Theophilides \& Stylianides (2000, cited in Saitis 2007: 147):

- A vision for the school he runs.

- Ability to transform, i.e. the ability to produce a specific project by transforming, transfiguring and changing the goals, the assets and the necessary resources.

- Empowerment of teachers through their involvement in the decision-making process, in order to acquire the necessary power of self-activation.

- Stability and conscious action, which are related to his ability to bring about changes that will benefit the course of the school unit.

- Creativity related to inventing and implementing radical solutions to deal with difficult situations.

- Sensitivity, expressed through the understanding he shows of the feelings, ambitions and needs of his subordinates.

- Professional completeness, i.e. the ability to have a significant impact on the teaching and administrative work of the school. To achieve all this however, a principal of a school unit needs to be properly trained, i.e. to receive specialized, theoretical and practical training, to be practiced in the subject of Educational Organization and Administration and in the management of various, actual events that take place in the daily school routine. In this way, he will be able to gradually help and be helped in dealing with and solving "school problems".

In addition, he must acquire specific pedagogical, social, didactic and technological skills, which are considered necessary and are required for the smooth 
administration of the school unit. At the same time, he should be aware that the participation of teachers in decision-making, with the ultimate goal of improving school teaching and learning, plays an important role in the smooth and effective operation of the school. The same happens when the power of persuasion is used to apply decisions, as well as when developing attitudes and behaviors that are based on a creative spirit and democratic climate and flexibility of thinking are especially important for people who hold positions of administrative responsibility (Stamatis, 2013).

Communication skills have the power to contribute to the transformation of the school unit, which will take place gradually, utilizing the excellent interpersonal relationships of cooperation and partnership to achieve common goals. If these happen, then the principal will be designated as flexible and open to new ideas and publicly praise the efforts of fellow teachers. In addition, he will critique with discretion and prudence, he will be objective and show respect for the personality of subordinates. In conclusion, the director of any educational institution, as a true leader, he must inspire and empower, he must effectively solve the problems that arise and have knowledge of social psychology since the handling of the human factor is a complex and extremely difficult and delicate affair.

\section{About the Authors}

Dr. Panagiotis J. Stamatis (BA, BA, PGDE, PhD) is an Associate Professor of Communication Education at the Department of Sciences of Preschool Education and Educational Design, University of the Aegean, Greece. His studies are focused on Preschool and Elementary School Education. His main research interests are concentrated on the field of instructional and family communication and on school communication violence approaching it as a barrier for addressing bullying and bias problems among children and/or teachers. Furthermore, he approaches educational communication as a key factor for improving interpersonal relationships among school community and family members. He has long term and great experience in school teaching, school administration and school counseling.

Georgios A. Gkoutziamanis (BA, MEd) is a PhD student at the Department of Preschool Education Sciences and Educational Design, University of the Aegean, Greece. His main studies are focused on Primary Education (Teaching, Administration, School Design and Development). He has great experience on elementary school administration issues.

\section{References}

Adrews, R. L., \& Soder, R. (1987). Principal Leader and Student Achievement. Educational Leadership, 44(6), 9-11.

Ahment, Z., Navaz, A., \& Khan, I. U. (2016). Leadership Theories and Styles: A Literature Review. Journal of Resources Development and Management, 16, 1-7. 
Athanasoula-Reppa, A. (2008). Educational Administration and Organizational Behavior. Athens: Ellin.

Bass, B. M. (1990). Bass and Stogdill's Handbook of Leadership: Theory, Research and Managerial Applications. Free Press.

Bass, B. M. (1997). Transformational Leadership: Industrial, Military, Educational Impact. Psychology Press.

Bennett, N., Crawford, M., \& Cartwright, M. (2002, Eds.), Leadership and Effective Education. London: Paul Chapman Publishing.

Bourantas, D. (2005). Leadership: The road of constant success. Athens: Kritiki.

Cheng, Y. C. (2002). The Changing Context of School Leadership: Implications for Paradigm Shift. In K. Leithwood et al. (Eds), Second International Handbook of Educational Leadership and Administration. Springer International Handbooks of Education, vol 8. Springer, Dordrecht. https://doi.org/10.1007/978-94-010-0375-9 5

Everard, K. B., \& Morris, G. (2004). Effective School Management. P. Chapman Publ. Ltd. Hanson E. M. (1996). Educational Administration and Organizational Behavior. Toronto: Allyn and Bacon.

Kantas, A. (1998). Organizational-Industrial Psychology. Athens: Hellenic Grammata.

Kets de Vries, M. F. R. (2009). The Leadership Mystique: Leading Behavior in the Human Enterprise. Prentice Hall.

Likert, R. (1961). New Patterns of Management. New York: McGraw Hill.

Makrigiorgakis, M. (2001). The Human Side of Management. Athens: Papazisis.

Mortimore, P. (1992). Issues in School Effectiveness. In D. Reynolds and P. Cuttance (Eds.), School effectiveness, research, policy and practice. London: Cassel.

Owens, R. (2001). Organizational Behavior in Education. Allyn \& Bacon.

Pasiardis, P. (2004). Quality in Administration of $21^{\text {st }}$ century Educational Organizations. In A. Andrew (Ed.), Organization and School Units' Administration. Athens: Institute of Employment.

Saitis, C. (2005). Organization and Administration of Education. Athens: Self-Publishing.

Saitis, C. (2007). Administrator in a Modern School. Athens: Self-Publishing.

Stamatis, P. J. (2011). Communication in Educational and Administrative Process: Basic concepts and strategies. Athens: Diadrassi Publications.

Stamatis, P. J. (2013). Communication in Education. Athens: Diadrassi Publications.

Stamatis, P. J., \& Hatzinikolaou, A. M. (2020). Practices of Greek school principals for improving school climate as communication strategy. European Journal of Human Resource Management Studies, 4(2), 93-107.

Theophilides, C. (1994). Orthological Organization and School Administration. Nicosia: SelfPublishing.

Theophilides, C., \& Stylianides, M. (2000). Philosophy and Practice of Elementary School Administration in Cyprus. Nicosia: Self-Publishing.

Vitsilaki, C., \& Raptis, N. (2007). Leadership and Educational Units' Administration. Thessaloniki: Kyriakides Bros.

Zavlanos, M. (1998). Management. Athens: Ellin. 

will be applied to their work. Under the terms of this license, no permission is required from the author(s) or publisher for members of the community to copy, distribute, transmit or adapt the article content, providing a proper, prominent and unambiguous attribution to the authors in a manner that makes clear that the materials are being reused under permission of a Creative Commons License. Views, opinions and conclusions expressed in this research article are views, opinions and conclusions of the author(s). Open Access Publishing Group and European Journal of Education Studies shall not be responsible or answerable for any loss, damage or liability caused in relation to/arising out of conflicts of interest, copyright violations and inappropriate or inaccurate use of any kind content related or integrated into the research work. All the published works are meeting the Open Access Publishing requirements and can be freely accessed, shared, modified, distributed and used in educational, commercial and non-commercial purposes under a Creative Commons Attribution 4.0 International License (CC BY 4.0). 